\title{
ANTIBACTERIAL ACTIVITY OF KAFFIR LIME LEAVES (Citrus hystrix) ON SELECTED FOODBORNE PATHOGENS
}

\author{
BAZLEE ABU BAKAR*, CHE PUTEH OSMAN and WAN RAZARINAH WAN ABDUL RAZAK \\ Faculty of Applied Sciences, Universiti Teknologi MARA, \\ 40450 Shah Alam, Selangor, Malaysia \\ *E-mail: bazleeabubakar@gmail.com
}

Accepted 6 March 2021, Published online 30 March 2021

One of the major problems that cause harm to humans and food spoilages is the microorganism contaminating the food. The survival of the microbes in food is a crucial issue which can lead to the spoilage and reduce the quality of food products and also cause harm to human if they are being ingested (Celiktas et al., 2007). Food poisoning is usually caused by ingesting food containing microbes that can be harmful to humans. These microbes would usually produce toxins and also gas in which will give a bad side effect on humans. It was reported that in Malaysia the cases of food poisoning increase by the rate of 62.47 cases in 100,000 people (Soon et al., 2017). Centers for Disease Control and Prevention (CDC), 2017, had stated that foodborne diseases are caused mainly by bacteria, parasites, and viruses in which Salmonella and $S$. aureus are on the top list for bacteria that can cause illness via food. Kaffir lime leaves or in Bahasa Melayu known as "daun limau purut", is a type of common aromatic plant in Malaysia that people used in cooking as an ingredient and have been reported to contain many benefits (Wongpornchai, 2012). It belongs to the citrus family and has the potential to inhibit biofilm produced by Streptococcus mutans (Kooltheat et al., 2016). Besides, according to Srifuengfung et al. (2020), antibacterial oral sprays which are derived from kaffir lime leaves oil and kaffir lime fruit oil was proven to be effective against respiratory tract pathogens. Thus, the initial work presented here focused on the antibacterial activity of kaffir lime leaves extracts on selected foodborne pathogens namely Salmonella typhi ATCC 14028, Staphylococcus aureus ATCC 25923, Bacillus cereus ATCC 11778, and Escherichia coli ATCC 25922.

Kaffir lime leaves were washed first before being left dried in an oven at $30^{\circ} \mathrm{C}$ until a constant weight was obtained. Then, the dried leaves were grounded by using a blender into powder form. As for the

* To whom correspondence should be addressed. preparation of extract, $200 \mathrm{~g}$ of powdered leaves were soaked with $500 \mathrm{~mL}$ of distilled water for 5 days and were kept inside a refrigerator to preserve the samples. Next, the soaked leaves were boiled for 1 $\mathrm{hr}$ and then filtered by using a filter paper (Whatman no 4.) before placing them in a freezer at $-20^{\circ} \mathrm{C}$. Later, the samples were placed in a freeze dryer, and extracts obtained were prepared into concentrations of $150 \mathrm{mg} / \mathrm{mL}, 200 \mathrm{mg} / \mathrm{mL}, 250 \mathrm{mg} / \mathrm{mL}$ by mixing the powdered extract with distilled water. Next, the agar disc diffusion method and broth microdilution method were performed according to the Clinical and Laboratory Standard Institute (CLSI, 2019). The 24 hr bacterial cultures were placed inside culture bottles that contained saline and were compared with $0.5 \mathrm{McF}$ arland standard $\left( \pm 1.0 \times 10^{8} \mathrm{cfu}\right)$ (Hardy Diagnostics) and $0.5 \mathrm{~mL}$ bacteria suspensions were spread on MHA (Mueller Hinton agar, Oxoid CM0337). Next, $6 \mathrm{~mm}$ blank paper discs (Oxoid antimicrobial susceptibility test disc) were dipped into the kaffir lime leaves extract and were placed on the agar and incubated overnight at $37^{\circ} \mathrm{C}$. Then, the agar plates were observed for clear inhibition zones and the diameter of inhibition zones was measured (Yildrim et al., 2017). The antibiotic Gentamicin disc (CN,10, Oxoid) was used as a positive control and distilled water was used as a negative control. This was repeated three times to obtain mean \pm SEM and data was analyzed by one-way ANOVA (Sample size, $n=48$ ) (IBM SPSS Statistic 22, 2013). The broth microdilution method was used to determine the minimum inhibitory concentrations (MICs). An amount of $0.5 \mathrm{~mL}$ of sterile MHB (Mueller Hinton broth, SRL 49550(MM0210)) was added into the wells of the microtiter plate (HmbG PO458 Microplate 96 wells Flat Bottom) and $0.5 \mathrm{~mL}$ of the kaffir lime leaves extract was added into the first well. Serial dilution was performed from the first well to the eighth well. The ninth well was used as a control. Then, $0.2 \mathrm{~mL}$ of the bacteria suspension was added to all of the wells and then incubated overnight. 
Table 1. Mean \pm SEM of the diameter of inhibition zone $(\mathrm{mm})$ of KLLE on foodborne pathogens

\begin{tabular}{lccccc}
\hline \multirow{2}{*}{ Sample } & $\begin{array}{c}\text { Concentration } \\
(\mathrm{mg} / \mathrm{mL})\end{array}$ & S. typhi & S. aureus & B. cereus & E. coli \\
\cline { 3 - 6 } & 150 & $7.33 \pm 0.33$ & $7.33 \pm 0.33$ & $\mathrm{NIZ}$ & $6.83 \pm 0.17$ \\
$\mathrm{KLLE}$ & 200 & $7.67 \pm 0.33$ & $7.83 \pm 0.44$ & $\mathrm{NIZ}$ & $7.00 \pm 0$ \\
& 250 & $7.67 \pm 0.33$ & $8.17 \pm 0.17$ & $\mathrm{NIZ}$ & $7.67 \pm 0.33$ \\
& 300 & $8.67 \pm 0.67$ & $8.17 \pm 0.17$ & $\mathrm{NIZ}$ & $8.33 \pm 0.88$ \\
Gentamicin $(+)$ & - & 16 & 20 & 21 & 17 \\
$\mathrm{dH}_{2} \mathrm{O}(-)$ & - & $\mathrm{NIZ}$ & $\mathrm{NIZ}$ & $\mathrm{NIZ}$ & $\mathrm{NIZ}$ \\
\hline
\end{tabular}

KLLE: Kaffir lime leaves extract, NIZ: No inhibition zone.

Table 2. MIC $(\mathrm{mg} / \mathrm{mL})$ and $\mathrm{MBC}(\mathrm{mg} / \mathrm{mL})$ of $\mathrm{KLLE}$ on foodborne pathogens

\begin{tabular}{lcccc}
\hline & S. typhi & S. aureus & B. cereus & E. coli \\
\hline MIC KLLE $(\mathrm{mg} / \mathrm{mL})$ & 150 & 100 & - & 100 \\
MBC KLLE $(\mathrm{mg} / \mathrm{mL})$ & 150 & 100 & - & 100 \\
MBC/MIC ratio & 1 & 1 & - & 1 \\
\hline
\end{tabular}

-: Not available.

Next, resazurin dye was added into all of the wells and incubated for $24 \mathrm{hr}$. The growth of bacteria was observed by the color changed from dark blue to pink. The lowest concentration of extract without growth was taken as MIC (Hastey et al., 2017). Minimum bactericidal concentration (MBC) was determined by sub-culturing the identified MIC content onto the MHA (Mueller Hinton Agar, Oxoid CM 0337) and was incubated for $24 \mathrm{hr}$. The agar plates with no bacterial growth were taken as the MBCs.

Results (Table 1) showed that at concentration $150 \mathrm{mg} / \mathrm{mL}$ clear inhibition zones were observed against $S$. typhi, $S$. aureus and $E$. coli are $7.33 \pm 0.33$ $\mathrm{mm}, 7.33 \pm 0.33 \mathrm{~mm}$, and $6.88 \pm 0.17 \mathrm{~mm}$ of mean values of the diameter of inhibition zone respectively while at a concentration of $200 \mathrm{mg} / \mathrm{mL}$, the mean values of the diameter of inhibition zone obtained are $7.67 \mathrm{~mm} \pm 0.33 \mathrm{~mm}$ against $S$. typhi, $7.83 \pm 0.44 \mathrm{~mm}$ against $S$. aureus and $7.00 \pm 0 \mathrm{~mm}$ against $E$. coli. At a concentration of $250 \mathrm{mg} / \mathrm{mL}$, clear inhibition zones were observed against $S$. typhi, E. coli, and $S$. aureus with mean values of the diameter of inhibition zone were $7.67 \pm 0.33 \mathrm{~mm}, 7.67 \pm 0.33 \mathrm{~mm}$, and $8.17 \pm 0.17 \mathrm{~mm}$ in diameter respectively. At a concentration of $300 \mathrm{mg} / \mathrm{mL}$, the highest mean value of diameter was obtained against $S$. typhi with the value of $8.67 \pm 0.33 \mathrm{~mm}$ followed by $S$. aureus and $E$. coli in which the values were at $8.33 \pm 0.33 \mathrm{~mm}$ and $8.33 \pm 0.88 \mathrm{~mm}$ in diameter. Unfortunately, there were no inhibition zones observed against $B$. cereus. As for the MICs and MBCs (Table 2), $150 \mathrm{mg} / \mathrm{mL}$ were obtained against $S$. typhi, $100 \mathrm{mg} / \mathrm{mL}$ against $S$. aureus and $E$. coli. If the $\mathrm{MBC} / \mathrm{MIC}$ ratio $\leq 4$, the effect of the extract will be taken as bactericidal, but if the MBC/MIC ratio is $\geq 4$, the effect of the extract will be taken as bacteriostatic (Levison, 2004; Thomas et al., 2012; Mogana et al., 2020). Thus, this extract is bactericidal to S. typhi, E. coli, and $S$. aureus. According to Yasurin (2015), compounds identified in kaffir lime leaves were terpenoids, monoterpenes, oxygenated monoterpenes, sesquiterpenes, citronellic acid, nerolidol, $\delta$-cadinene, citronellal, and citronellol. These compounds were responsible for kaffir lime leaves exhibiting antimicrobial properties. This was supported by Siripongvutikorn et al. (2015) which found that the extract of kaffir lime leaves showed antibacterial activity against $S$. aureus as well as on $E$. coli in which the diameter of the inhibition zone was less than $9 \mathrm{~mm}$. As a conclusion, kaffir lime leaves extract exhibited antibacterial activity on $S$. aureus, S. typhi, and E. coli except on B. cereus with the most effective was demonstrated against $S$. typhi at $300 \mathrm{mg} / \mathrm{mL}$ concentration with $8.67 \pm 0.67$ $\mathrm{mm}$ diameter of inhibition zone. The increase in extracts concentration can also increase the antibacterial activity of the extracts.

\section{ACKNOWLEDGEMENTS}

Authors gratefully acknowledge Universiti Teknologi MARA in providing the GIP research grant (Project Number:600-IRMI 5/3/GIP(026/2019), Faculty of Applied Sciences, Universiti Teknologi MARA, Shah Alam, Selangor, Malaysia. 


\section{REFERENCES}

Celiktas, O.Y., Bedir, E. \& Sukan, F.V. 2007. In vitro antioxidant of Rosamrinus officinalis extracts treated with supercritical carbon dioxide. Food Chemistry, 101: 1457-1464.

Centers for Disease Control \& Prevention. 2017. Fungal diseases. Outbreaks and investigations [WWW Document]. URL http://cdc.gov/fungal/ outbreak (accessed 08.16.2020).

Clinical and Laboratory Standards Institute (CLSI). 2019. Performance standards for antimicrobial susceptibility testing [WWW Document]. URL http://clsi.org/standards/products/microbiology/ documents/m100 (accessed 11.29.2020).

Hastey, C.J., Dale, S.E., Nary, J., Citron, D., Law, J.H., Roe-Carpenter, D.E. \& Chesnel, L. 2017. Comparison of Clostridium difficile minimum inhibitory concentrations obtained using agar dilution vs broth microdilution methods. Anaerobe, 44: 73-77.

Kooltheat, N., Kamuthachad, L., Anthapanya, M., Samakchan, N., Sranujit, R.P., Potup, P. \& Usuwanthim, K. 2016. Kaffir lime leaves extract inhibits biofilm formation by Streptococcus mutans. Nutrition, 32(4): 486-490.

Levison, M.E. 2004. Pharmacodynamics of antimicrobial drugs. Infectious Disease Clinics of North America, 18(3): 451-465.

Mogana, R., Adhikari, A., Tzar, M.N. \& Wiart, C. 2020. Antibacterial activities of the extracts, fractions and isolated compounds from Canarium patentinervium Miq. against bacteria clinical isolates. BMC Complementary Medicine and Therapies, 20(55): 1-11.
Siripongvutikorn, S., Thummaratwasik, P. \& Huang, Y.-W. 2015. Antimicrobial and antioxidation effects of Thai seasoning, Tom-Yum. LWT Food Science and Technology, 38(4): 347-352.

Soon, J.M., Singh, H. \& Baines, R. 2011. Foodborne diseases in Malaysia: A review. Food Control, 22(6): 823-830.

Srifuengfung, S., Bunyapraphatsara, N., Satitpatipan, V., Tribuddharat, C., Junyaprasert, V.B., Tungrugsasut, W. \& Srisukh, V. 2020. Antibacterial oral sprays from kaffir lime (Citrus hystrix DC.) fruit peel oil and leaf oil and their activities against respiratory tract pathogens. Journal of Traditional Medicine and Complementary Medicine, 10(6): 594-598.

Thomas, B.T., Adeleke, A.J., Raheem-Ademola, R.R., Kolawole, R. \& Musa, O.S. 2012. Efficiency of some disinfectants on bacterial wound pathogens. Life Science Journal, 9(2): 752-7551.

Wongpornchai, S. 2012. Handbook of Herbs and Spices. Woodhead Publishing Limited, United Kingdom. 321 pp.

Yasurin, P. 2015. Antimicrobial properties of common herbs and spices used in Thai cooking. Research Journal of Pharmaceutical, Biological and Chemical Sciences, 6(1): 48-57.

Yildirim, S.T., Oztop, M.H. \& Soyer, Y. 2017. Cinnamon oil nanoemulsions by spontaneous emulsification: Formulation, characterization and antimicrobial activity. LWT-Food Science and Technology, 84: 122-128. 
